\title{
The Role of Community-based Health Practice on the Improvement of Healthcare Students' Communication, Empathy and Perception of the EIderly: A Qualitative Study at Izmir University of Economics
}

\section{Să̆lık Öğgrencilerinin İletişim, Empati ve Yaşlı Algısının Geliştirilmesinde Toplum Temelli Sağlık Uygulamasının Rolü: İzmir Ekonomi Üniversitesi’nde Nitel Bir Çalışma}

\author{
Zeynep AKSOY ${ }^{1}$, Özden GÖKDEMIR ${ }^{2}$ ๑, M. İlgi ȘEMİN ${ }^{3} \odot$
}

'Asst. Prof. Dr., Izmir University of Economics, Faculty of Communication, Public Relations and Advertising Department, İzmir, Turkey

${ }^{2}$ Asst. Prof. Dr., Izmir University of Economics, Faculty of Medicine, Department of Physiology, İzmir, Turkey

${ }^{3}$ Prof. Dr., İmir University of Economics, Faculty of Medicine, Department of Physiology, Izmir, Turkey

ORCID: Z.A. 0000-0002-0297-0372

Ö. G. 0000-0002-0542-5767;

M. İ. Ş. 0000-0001-8747-5145

\section{Corresponding author:}

Zeynep Aksoy, İzmir Ekonomi Üniversitesi, Iletişim Fakültesi, İzmir, Türkiye

E-posta/E-mail:

zeynep.aksoy@ieu.edu.tr

Received: 12.10 .2020

Revision Requested: 18.10 .2020

Last revision received: 17.03 .2021

Accepted: 06.02.2021

Citation: Aksoy, Z., Gökdemir, Ö., \& Şemin, M. I. (2021). The role of community-based health practice on the improvement of healthcare students' communication, empathy and perception of the elderly: A qualitative study at Izmir University of Economics. Connectist: Istanbul University Journal of Communication Sciences, 61, 33-51.

https://doi.org/10.26650/CONNECTIST2021-0088

\section{ABSTRACT}

Interpersonal communication involving empathy is of great importance in therapeutic relationships in healthcare. To equip medical/healthcare students with interpersonal communication skills, community-based health education provides real-life contexts in which they engage with the community as part of the curriculum. A community-based health practice (CBHP) was implemented at Izmir University of Economics (IUE) to improve students' communication, empathy and perception towards the elderly. Within an interdisciplinary collaboration among the medicine, nursing, elderly-care and physiotherapy programs, a total of 111 students participated in the project. This study aimed to evaluate the role of the CBHP on students' communication, empathy and perception of the elderly. Taking a qualitative approach, focus group interviews were organized with students $(n=22)$. Descriptive analysis of the qualitative data revealed that students witnessed the loneliness of elderly individuals, their physical and psychosocial needs, which resulted in a high degree of empathy. Furthermore, the study also aimed to gain insights from elderly participants via in-depth interviews $(n=9)$. Results demonstrated that the participants felt valued and useful during the communication processes with the students. In conclusion, CBHP contributed to students' perceptions and empathy towards the elderly; meanwhile the elderly individuals were satisfied with the interest of the medical, nursing and healthcare students.

Keywords: Community-based practice, healthcare, interpersonal communication, empathy, perception of elderly 
ÖZ

Empati içeren kişiler arası iletişim, sağlık hizmetlerindeki terapötik ilişkilerde büyük önem taşımaktadır. Tıp/sağlık öğrencilerine kişiler arası iletişim becerileri kazandırmak için toplum temelli sağlık eğitimi müfredatın bir parçası olarak toplulukla etkileşime girdikleri gerçek yaşam bağlamları sağlamaktadır. Öğrencilerin iletişim, empati ve yaşlılara karşı algılarını geliştirmek için İzmir Ekonomi Üniversitesi'nde (IEU) toplum temelli bir sağlık uygulaması gerçekleştirilmiştir. Tıp, hemşirelik, yaşlı bakımı ve fizyoterapi programları arasında disiplinler arası bir iş birliği içinde, toplam 111 öğrenci projeye katılmıştır. Bu çalışma, toplum temelli sağlık uygulamasının öğrencilerin iletişimi, empatisi ve yaşıı algısı üzerindeki rolünü değerlendirmeyi amaçlamıştır. Niteliksel yaklaşım ile öğrenciler ile odak grup görüşmeleri gerçekleştirilmiştir $(n=22)$. Niteliksel verinin betimsel analizi, öğrencilerin, yaşı bireylerin yalnızlığına, fiziksel ve psikososyal gereksinimlerine yakından tanıklık etmelerinin yüksek düzeyde empatiye yol açtığını ortaya koymaktadır. Ayrıca çalışmada yaşlı katılımcılardan yüz yüze görüşmeler yoluyla içgörü elde edilmesi amaçlanmıştır $(n=9)$. Araştırma sonuçları katılımcıların öğrenciler ile iletişim süreçleri esnasında değerli ve faydalı hissettiklerini göstermektedir. Sonuç olarak, toplum temelli sağlık uygulaması öğrencilerin yaşı algısına ve empatisine katkı sağlamış, aynı zamanda yaşı bireyler tıp, hemşirelik ve sağlık hizmetleri öğrencilerinin gösterdikleri ilgiden memnun kalmışlardır.

Anahtar Kelimeler: Toplum temelli uygulama, sağlık hizmeti, kişiler arası iletişim, empati, yaşıı algısı

\section{INTRODUCTION}

Communication skills accompanied by empathy are expected to be demonstrated by the twenty first century's doctors, nurses and other healthcare providers. From a holistic health perspective, which refers to approaching humans as a whole with body, mind, and soul (Wade, 2009, p. 5), healthcare professionals must show empathy to their patients, and manage communication processes in a humanistic way. With this aim, medical and healthcare education institutions attempt to enrich their curriculums with communitybased education programs in order to provide students with real settings, in which they can interact with various groups in the community. Learning from people in the community rather than in a hospital is more likely to develop empathy towards the patients (Prihanti, 2017). Community-based education programs are planned to create a long-term effect on students' ability to show empathy and develop communication skills.

It has been widely accepted that high quality healthcare services can be achieved through a well-structured curriculum of undergraduate medical and healthcare education, in which community based learning is embraced (Bahar-Özvarış, 2007; Buttery \& Moser, 1980). The experience of the community setting is beneficial in providing meaningful learning outcomes, such as communication skills, patient management, empathy, and in developing medical students' attitudes, and the values of a 'doctor' in a real-world environment (Kelly, Walters, \& Rosenthal, 2014). As Corson (1998) points out "community-based education begins with people and 
their immediate reality" (p. 240). Community-based health education provides students with appropriate contexts to communicate and interact with patients/ individuals within out-of-class activities as part of the curriculum. It helps students to gain insights through real-world experiences (Mooney \& Edwards, 2001). As a milestone of medical education, The Edinburgh Declaration (1988) underlies community-based education, urging that medical education should be undertaken by involving all the resources of society (World Federation for Medical Education). With this perspective, community-based health education aims to implement a medical curriculum not only with students, but also with all the stakeholders of the community (Magzoub \& Schmidt, 2000). Therefore, medical schools often integrate CBHPs into their curriculums to prepare their students for the profession by providing them with real contexts, involving both students and various sections of society such as disadvantaged groups, patients or elderly people.

The practices of community-based health education may differ from school to school because of national policies, the complexity of the healthcare services, and approaches to health education. Boyer (1990) argues that the university and the faculty members should be "responsive to the needs and changes in the society" (p. 74). In order to identify the structure of community-based education programs, target populations and their needs should be well-defined (Hunt, Bonham, \& Jones, 2011). One section of the population that requires special attention is the elderly, which has been growing year by year both in developed and developing countries. By 2030, the number of people aged 65 years and above is projected to be nearly 21 percent of the total population of the United States (US Census Bureau, 2017). It is projected that one in four people in the United Kingdom will be aged 65 years and above by 2050 - an increase from approximately one in five in 2018 (Office for National Statistics, 2019). The elderly population is growing in Turkey, as well. It has been reported that the number of people aged 65 and above was 8 percent of the total population in 2014, increasing to 9 percent in 2018, and is projected to reach 13 percent in 2030 (Ministry of Health, Republic of Turkey 2018). Demographic projections point out that primary healthcare services for elderly people need to improve to meet this challenge. The prevention and management of diseases is becoming crucial because of the rapid demographic shift of the population and the increased numbers of people with complex morbidity (Yang et. al, 2008). Therefore, medical and healthcare students should have more opportunities to engage with elderly groups in order to gain positive attitudes, communication skills, and develop empathy. 
Being a vital component of interpersonal communication competence, empathy emerges as a core skill that is studied and discussed within the health communication field. A review of the literature reveals that quality communication driven by empathy between doctor and patient has a positive impact on patient satisfaction (Clever et al., 2008), job satisfaction (Maguire \& Pitceathly, 2002), and results in improved health (Stewart, 1995). Gholamzadeh et al. (2018) suggest that training programs are beneficial in improving students' empathy and attitudes towards the elderly. In a broader sense, empathy involves understanding others' emotions and thoughts. The concept of empathy refers to a capacity which allows individuals "to know what other people think and feel, to emotionally engage with them, to share their thoughts and feelings, and to care for their well-being" (Stueber, 2019). Having an important role in therapeutic relationships, empathy "involves an understanding of experiences, concerns, and perspectives of the patient, combined with a capacity to communicate this understanding, and an intention to help" (Hojat, DeSantis, \& Gonnella, 2017, p. 78). Therefore, medical and healthcare education attempts to equip students with communication skills. CBHP provides real settings for students to experience "interacting, communicating and empathizing with the communities" (Prihanti, 2017, p. 98). In this respect, communitybased practices become more important for achieving learning outcomes through structuring contexts for future doctors and healthcare providers to experience communication processes with the community members.

A review of the literature reveals a lack of research on community-based education in Turkey, yet a few studies examine patient groups in community-based settings (Cevizci et al., 2015; Çalışkan et al., 2007; Şimşek et al., 2014; Turan \& Say, 2003). Currently, there is a lack of projects combining medical and healthcare curriculums with CBHPs and evaluations of their outcomes. Aiming to implement CBHP within the medical education curriculum, a house-visit project was developed at IUE to enable students to engage with the community in which they will eventually serve. CBHP objectives included collecting health-related data from elderly individuals, evaluating in-house safety risks, learning the concerns and expectations of the community, and developing the communicative and cooperative skills of the students as team members. This article presents the research conducted following the CBHP. The strength of this study rests in the narrations collected both from student and elderly samples, resulting in in-depth insight from the two parties of the CBHP. Since it is original research on multidisciplinary community-based education with the elderly in Turkey, the study is important as it sheds light on the reciprocity relationships in community-based practices by evaluating the narrations of both parties. 
With respect to the insight gained from the research, the article presents implications for further community-based practices aimed at improving interpersonal communication competences among various community members.

\section{AIM AND METHODOLOGY}

Current CBHP, which has been implemented at IUE, focuses on elderly people from a multidisciplinary perspective, combining medical and healthcare students in working teams. Adopting a qualitative approach, this study seeks to understand how students make sense of their experiences with elderly individuals during the CPHP. In addition, the scope of the study was expanded to include interviews with elderly participants. While, students' experiences provided an in-depth understanding about how they developed empathy and perception towards elderly people, the feedback obtained from elderly participants further enabled them to comprehend how they have benefited from the CBHP.

\section{Aim}

This study aimed to understand the ways in which a CBHP contributes to students' communication, empathy and perception towards the elderly, and to gather feedback from the elderly individuals about the practice and the communication processes with the students. In light of the insights gained from both groups, recommendations are provided for future practices in order to enrich learning experiences in medicine, nursing and healthcare services. In accordance with this aim, the study examines the following research questions:

RQ1: In which ways does the CBHP contribute to healthcare students' perceptions of the elderly?

RQ2: To what extent does the CBHP contribute to healthcare students' empathy towards the elderly?

RQ3: How do the healthcare students make sense of their experiences with the elderly regarding the communication processes?

RQ4: In which ways do the elderly benefit from the CBHP?

\section{Methodology}

This study adopted a phenomenological pattern in a qualitative approach by using focus group interviews to understand the role of the CBHP on students' perceptions 
and empathy towards the elderly. As Sundler et al. (2019) point out, the experiences of human beings are focused on and described in phenomenological research. Descriptive phenomenology involving semi-structured interviews is commonly used both in communication and healthcare studies. Being a prominent method in communication studies, focus groups have also become popular in health education and health related issues (Kitzinger, 1995). The advantage of focus group interviews is using the interaction between participants in order to explore people's experiences, meanings and understandings (McLafferty, 2004). In this respect, focus group interviews provided an in-depth understanding as to how participants in the CBHP made sense of their real life experiences with the elderly community.

To gain insights from the elderly individuals about the project and their experiences, in-depth interviews were conducted. As Boyce (2006) describes, "in-depth interviews offer a more complete picture of what happened in a program and why" (p. 3). Therefore, interviewing a group of elderly participants in the project enriched the results of the research.

\section{Participants in the study}

The CBHP was coordinated among four programs of the university: medicine (36 second year students), nursing (31 third year students), elderly care, and physiotherapy (first and second year 44 students), in the 2018-19 academic year ( $N=111)$. The students were matched in pairs from the Medicine-Nursing and Elderly Care-Physiotherapy programs. Prior to the house-visits, students were provided with lectures on biopsychosocial features in the elderly, geriatric risk factors, and communication skills.

Within the scope of the project, the community was designated as the university district, Balçova. Approximately 120 elderly individuals were chosen with the collaboration of the district municipality. Previously informed elderly individuals were visited at home by faculty members who gave them information about the project. The final group was composed of 45 elderly individuals, who gave consent for the house-visits. Appointments were arranged by the faculty members. Each student group visited the assigned elderly person three times during a six week period. Students performed structured procedures, such as collecting health data, providing information about in-house safety, well-being, and engaging in everyday conversations. 
Once the house-visits were completed by all groups, semi-structured focus group interviews were organized. Of the students in the four programs, 22 students ( 18 females and 4 males) were randomly selected to participate in focus group sessions (Table 1). The sessions were organized between May 16-21, 2019. The consent of the participants was obtained. For confidentiality, student quotes are identified by group and participant numbers. Ethical approval was obtained from the IUE ethical committee.

The second part of the study involved in-depth interviews with the elderly participants in order to understand their views regarding the CBHP and the communication processes they had experienced with the students. The sample size of this study was identified in accordance with the demographics of the elderly group (31 females and 14 males, average age=78). A sample group included 7 females and 3 males (average age $=78$ ) based on voluntary participation. As one elderly male was unable to host the researchers at the appointed date and time due to health issues, nine face-to-face interviews were conducted.

\section{Procedure}

A focus group guideline was used during the sessions. The students were asked to describe their experiences with elderly individuals (either positive or negative), how they had resolved any communication issues, their perceptions of the elderly, and their experiences of working as a team. These sessions were moderated by a researcher with no previous interaction with the students. The independent position of the moderator enabled a space where participants could express themselves freely. Each focus group session lasted approximately one hour. All focus group sessions were audio-visually recorded with the consent of the participants.

In the second part of the study, a semi-structured interview form was used to conduct in-depth interviews with the elderly participants. Interview questions aimed to understand their attitudes towards the project and the communication processes with the students. Each interview lasted for around one hour. All interviews were audiorecorded with the consent of the participants.

\section{Qualitative data analysis}

A descriptive analysis was performed on the qualitative data, moving from the original data obtained in the focus groups and interviews towards the organization of 
the themes in relation with the research questions. In this process, the qualitative data was analyzed without any sort of an identified framework in advance (Burnard et al., 2008), meaning that data driven themes were derived from the analysis (Sundler et al., 2019). First, audio-visual recordings of the focus groups and interviews were transcribed verbatim (quotes given in this article were reproduced without distorting the meanings). Transcribed material was examined by the researchers separately in order to establish inter-coder reliability. Afterwards, the texts were reviewed and discussed together by the researchers, and the emerging themes were identified. During this descriptive analysis process, the researchers' efforts were directed at exploring meanings through rereading of the textual material, organizing them in relation to the research aim and questions.

\section{FINDINGS}

In relation to the research questions, the focus group sessions involved questions addressing students' perception and attitudes towards the elderly, and their communication experiences. The findings provided an in-depth understanding about the role of the CBHP under three emerging themes, which were as follows:'descriptions of the elderly', 'understanding the elderly', and 'communicating with the elderly'.

The final research question was determined to gain insights from the elderly participants. Interviews with the elderly individuals provided significant findings about their thoughts regarding the house-visit practice and the communication processes they were involved in. The findings derived from the interviews highlighted two key themes: 'the sense of being useful' and 'eliminating the sense of loneliness'.

\section{Experiences of the students: "She needs nothing, just another human."}

\section{Descriptions of the elderly}

Students were asked to express what they attributed to the term 'elderly'. Students often used the following terms: ill-tempered, lonely, stubborn, unhappy, depressed, vulnerable and sensitive to describe elderly people. During the sessions, the participants often referred to the concept of helplessness when narrating their experiences with the elderly in house-visits. 'I saw clearly that they were helpless', a student stated (Focus group 4, P20). Another student reported: 
He was crying constantly. He saw children playing on the street and cried saying "they reminded me of my childhood". He saw us and cried, for example, he said that "no one opened my door, but you". We actually tried to comfort him (Focus group 1, P2).

Observing and interacting with the elderly in their own houses allowed students to directly witness their socioeconomic conditions, health-related problems, concerns and needs. It was observed that students' descriptions in general pointed out the weaknesses of the elderly. On the other hand, a few students expressed relatively positive characteristics, such as experienced and cute. At this point, the data was examined in terms of the relationship between students' descriptions and their previous experiences with the elderly. Qualitative data demonstrated that the length of experience with older family members seemed to be an indicator of the descriptions. As an example, a student who described the elderly as ill-tempered, stated the following:

I was more relaxed compared to my friends. I have been living with old people since 2008. I took care of my grandfather until he died, and afterwards I began to live with my grandmother. I have been with elderly people for 10 years; their friends, their reunions, all the time with elderly people. I am experienced (Focus group 3, P12).

Another student, who described the elderly as cute, stated:

I just lost my grandmother. ... I already love old people very much. I had been living with my grandmother for 20 years. So, it was not a different experience for me. I became happy when they were happy (Focus group 2, P8).

\section{Understanding the elderly}

When narrating their experiences with the elderly during house-visits, students described various situations highlighting their developing understanding of the elderly. Narrations show that the students were able to closely observe their living conditions, which sometimes resulted in sadness, as one participant expressed:

I felt very sad in my last house-visit. She was so lonesome. She said about her daughter, "we are very close as we are so far away". Her eyes were full of tears. ... 
She is afraid of loneliness, she cried. I felt bad, but tried not to reflect it to her. When I left the house, I called my mother. My eyes were full of tears while talking to her (Focus group 1, P2).

Students reported that their dialogues with elderly individuals led to an understanding of their needs, and to a sense of empathy. One of the participants stated:

The elderly person whom I visited had big issues; she had osteoporosis; she didn't have a walking frame to go outside; she was afraid of climbing the stairs. She thought that we were there to help with these issues (Focus group 2, P7).

When the moderator asked how they responded to such expectations, a participant responded as follows:

She thought that I was there to cure her. I told her that she needed to go to hospital. But, I measured her blood pressure, for instance, and she became happy (Focus group 2, P9).

Another student's perspective was slightly different: 'The lady was eighty-four and living alone. She needs nothing, just another human' (Focus group 1, P4).

Some narrations show that students'empathy tended to cause a feeling of helplessness when faced with sorrow. A student described it as follows:

The person we visited was very emotional. She was questioning her past all the time. She was expressing her regrets... and she had expectations from us, like "are you going to be a solution for my problems? or are you going to provide me a hearing aid?". But, as students, we do not have such opportunities. Frankly, I questioned myself. ...I felt insufficient (Focus group 3, P16).

The qualitative data demonstrates that the students developed a previously unfelt degree of empathy towards the elderly. A participant admitted, 'I think we leave them alone so much' (Focus group 3, P11); another one agreed, stating 'there are so many elderly individuals, but we are not able to make them a part of our lives' (Focus group 3, P13). A student expressed her way of developing empathy as 'I was always aware of their difficulties, but I felt more intensively that they are unhappier than we are' (Focus 
group 4, P20). One of the students described the issue in a more empathetic way: 'We tend to see them as if they are different than us, but actually they are only the older versions of us' (Focus group 4, P19). It has been understood from the narrations that students often found themselves in the position of feeling what it is like to be elderly.

\section{Communicating with the elderly}

Participants were asked for their opinions on communication with an elderly individual. Students expressed various thoughts about the topic. One of the participants suggested that communication with the elderly must be'without considering that the person we are dealing with is old' (Focus group 3, P13). However, others disagreed: 'I think a bit of a careful approach is needed. Most of them complain of loneliness' (Focus group 3, P12); 'It requires gentler talk. They can be very touchy' (Focus group 3, P15); '...should be more respectful' (Focus group 3, P11).

During dialogues within the sessions, students expressed their thoughts on ways of communication. A student claimed:

The approach must be more careful. For example, when they question their past a lot, we can encourage them to try to see that the glass is half-full (Focus group 3, P16).

One of the students stated, 'I think staying calm is necessary, because there may be a lot of things making them cry. We should listen to them. They feel good when they share thoughts with us' (Focus group 4, P21), while another one continued as follows: 'I think we need to interrupt them at some point, because ...they can be distracted a lot. When you don't stop them, they keep talking, feel sad, and forget about the original subject' (Focus group 4, P20).

Participants also explained how CBHP contributed to their communication skills. A student explained as follows:

Personally, I think my communication skills are not very good. For me it was useful to learn about how I can initiate a dialogue, how the communication process develops. It was useful for me to be able to plan communication (Focus group 4, P22). 
Another student stated, 'we started simulation practice in another course. This practice helped me to be more comfortable there, because of the similar conversations' (Focus group 4, P18).

\section{In the eyes of the elderly people: "There is someone knocking on my door."}

The most important finding gained from the interviews is the sense of happiness they felt for being useful to the students. This apparent benefit from the practice was unforeseen. A participant described her feelings as: 'I became really happy as if I were of benefit to them. Maybe a few words of mine will be useful to them.... If I am going to be useful to young people, let them come again' (female, 66). Another also said: 'I would like to talk about life. I could give a summary of my life. I have a lot to tell, what I have gone through during my life' (male, 87). It has been understood that the elderly individuals felt useful during the CBHP as they were hosting young students who would be doctors or nurses in the future.

Elderly individuals also reflected their satisfaction with the house-visits for alleviating their sense of loneliness. A participant expressed her feelings as follows:'I felt joy. I felt there was a human next to me. It was nice to have support from someone' (female, 72). Others also stated 'they made me so happy. I appreciate very much that they came to my house and took care of me' (female, 86);'I need people. I stay at home all day long, I cannot go out. They became company for me' (female, 88). Elderly participants explained their loneliness in the same way that the students narrated in the focus groups. They seemed to have benefited from these visits mostly in social ways, as one of them simply stated, 'there is someone knocking on my door' (female, 80).

During the interviews, participants were requested to describe their impressions of the students' ability to communicate. All respondents were satisfied, as seen in their explanations: 'They were so mature, talking very gently' (female, 66). 'They were very sincere and friendly (female, 76). 'I do appreciate them. They are sensible' (male, 87). Data obtained from the interviews reveal that the elderly participants mostly gave positive evaluations about the house-visits and their communication processes. 


\section{DISCUSSION AND CONCLUSION}

Community based education involving CBHPs has been adopted in many medical schools around the world, rising from a need to better prepare students for the profession, and to support their engagement with the community, especially with disadvantaged groups. Within this perspective, a CBHP for the elderly community was implemented at IUE Medical School in 2019. The significance of the project lies in building collaboration among medicine, nursing, physiotherapy and elderly care students in order to encourage peer learning and interaction. This study reveals that medicine and healthcare students developed an understanding and empathy towards elderly people by visiting them in their own surroundings. Through combining medical education with a CBHP, future healthcare professionals are provided with an opportunity to leave their comfort zones, enriching their education with real-life experiences within a structured program.

The objectives of this project included engaging medical, nursing and healthcare students with the elderly community. Stereotyping of the elderly has a significant place in the literature. Allport's contact hypothesis (1954) suggests that an individual's interaction with outgroup members in a cooperative manner leads to positive attitudes towards the outgroup as a whole (Pettigrew, 1998). Further studies argue that quality of interactions is essential to the development of positive attitudes towards an outgroup (Schwartz \& Simmons, 2001). There are multiple stereotypes - positive and negative - of elderly people (Hummert, 1990). Hale (1998) suggests that individuals with a high level of contact with the elderly tend to reflect lower stereotyping. While it has been argued that young adults are likely to make negative associations about the elderly (Chasteen \& Pratt, 1999), more recent research points out that both young and old adults might demonstrate a positive bias towards the elderly (Chasteen, Schwarz, \& Park, 2002). Current research primarily questioned how medical and healthcare students perceive the elderly. Students were likely to describe the elderly by mentioning their living conditions, loneliness and vulnerability. Relatively negative attributions like ill-tempered and stubbornness do not seem to be an obstacle for showing empathy to elderly people.

Recent research emphasizes that the "exposure to the realities of the home environment provides deep learning experiences" (Pohl, Malin, \& Kennell, 2014, p. 697). In this study, real-life experiences allowed students to encounter disadvantaged elderly members of the community, mainly from low socio-economic groups, and resulted in 
more empathetic views and attitudes. As students closely witnessed the physical and psychosocial needs of the elderly individuals and gained an awareness of their situation, they had the opportunity to experience empathy. As described previously, empathy involves "the capacity to communicate and willingness to help" (Hojat, DeSantis, \& Gonnella, 2017, p. 78). In this sense, the study demonstrates the students' intention to understand the concerns of elderly people, and to support them in various ways.

However, it should be noted that some students already had close relationships with their older family members. Long-term previous experience with the elderly seemed to influence their perceptions and experiences during the project, a relationship supported by a few studies in the field. Söderhamn et al. (2001) suggest that limited previous experience is a significant factor in unfavorable attitudes towards the elderly. Olson's (2003) study shows that students who have a meaningful relationship with an elderly person had more positive attitudes. This study similarly suggests that long-term experiences with older adults may influence healthcare students' perceptions and empathy, although it still requires further investigation.

There have been a few studies conducted in various countries evaluating the impact of community-based education or training programs on students' empathy and perception of the elderly. The current literature emphasizes"the need of community-based education for learning of empathy" (Prihanti, 2017, p. 98). Gholamzadeh et al. (2018) claims that the empathy and attitudes scores of nursing students towards the elderly increased as a result of empathy skills training. As lack of empathy harms interpersonal communication, equipping medical and healthcare students with empathetic communication skills becomes crucial. Empathy in therapeutic relations is beneficial for the patients, as it helps to reduce professional stress (Hojat, DeSantis, \& Gonnella, 2017). This study demonstrates that the house-visit practice makes a significant contribution towards improving students' positive perceptions and empathy towards the elderly.

Examining the interpersonal communication skills of healthcare providers demonstrates that an affiliative or caring communication style, which embraces communication behaviors such as empathy, warmth, genuineness, compassion, and receives more favorable evaluations by patients (Buller \& Buller, 1987; Finkelstein, Carmel, \& Bachner, 2017). The results of this study demonstrate that medical and healthcare students are more likely to adopt a relationship-centered communication style by advocating caring and gentle behavior towards the elderly. Without doubt, 
this caring approach may be affected by several factors including student sociodemographic characteristics, professional competency or cultural values, which can be focused on extensively in future research.

The study also reveals that the CBHP created reciprocity between the two sides. Interviews with the elderly participants demonstrated their satisfaction with the housevisits project. Loneliness in the elderly is reported as an important physical, psychological and social health problem by the literature (Holmén \& Furukawa, 2002; Kharicha, 2017). Moreover, a better understanding of the patients not only improves healthcare services, but also makes patients feel valued (Chen et al., 2007). Community-based services for ameliorating elderly loneliness are recommended (Kharicha, 2017). In this CBHP, students reached an understanding of the sense of loneliness and related needs of the elderly; meanwhile, the elderly individuals felt valued through the communication processes during the house-visits. Furthermore, the study emphasizes that elderly participants were satisfied with the project as the house-visits gave them a feeling of supporting the students. This finding is also valid in Stacy and Spencer's (1999) study emphasizing that "the patients see themselves as teachers having specific contributions in students' training" (p. 693). In this respect, a CBHP for the elderly clearly supports the community members in various ways ranging from healthcare matters to interpersonal relations and the satisfaction of helping others.

To the best knowledge of the authors, the current literature reveals no studies on community-based health education and CBHPs for elderly people in Turkey. In this respect, this study has made a substantial contribution to the literature by implementing a CBHP for the elderly in Turkey and investigating its role in students' perceptions, attitudes and communication skills. Moreover, the study is unique in combining the narrations of participant students and elderly individuals, which enabled researchers to gain an indepth understanding of the role of the CBHP on reciprocity relationships between diverse members of society. Elderly participants' viewpoints enhanced the interpretation of the mutual interaction built up during the house-visits between the students and elderly.

The duration of the CBHP seems to be the main limitation of the study; the housevisits lasted for six weeks, raising doubts about the sustainability of the project. Communitybased education should adopt sustainable programs not only for achieving long-term learning outcomes, but also to support the elderly community, with its various needs, issues and expectations. Therefore, the long-term contributions of the community-based 


\section{health education to the students and the elderly community need further consideration. It is highly recommended that sustainable CBHPs be implemented to equip students with communication skills and to investigate the long-term effects on the community.}

Peer-review: Externally peer-reviewed.

Conflict of Interest: The authors have no conflict of interest to declare.

Grant Support: The authors declared that this study has received no financial support.

Author Contributions: Conception/Design of study: Z.A., Ö.G., M.I.Ş.; Data Acquisition: Z.A., Ö.G.; Data Analysis/Interpretation: Z.A., Ö.G., M.I.Ş.; Drafting Manuscript: Z.A., Ö.G., M.I.Ş.; Critical Revision of Manuscript: Z.A., Ö.G., M.I.Ş.; Final Approval and Accountability: Z.A., Ö.G., M.I.Ş.

Hakem Değerlendirmesi: Dış bağımsız.

Çıkar Çatışması: Yazarlar çıkar çatışması bildirmemiştir.

Finansal Destek: Yazarlar bu çalışma için finansal destek almadığını beyan etmiştir.

Yazar Katkısı: Çalışma Konsepti/Tasarımı: Z.A., Ö.G., M.I.Ş.; Veri Toplama: Z.A., Ö.G.; Veri Analizi /Yorumlama: Z.A., Ö.G., M.I.Ş.; Yazı Taslağı: Z.A., Ö.G., M.I.Ş.; İçeriğin Eleştirel İncelemesi: Ş.A.; Son Onay ve Sorumluluk: Z.A., Ö.G., M.I.Ş.

\section{REFERENCES}

Bahar-Özvarış, Ş. (2007). Topluma Dayalı Tıp Eğitimi (Community-based Health Education). Toplum Hekimliği Bülteni, 26(3), 1-6.

Boyce, C., \& Neale, P. (2006). Conducting in-depth interviews: A guide for designing and conducting in-depth interviews for evaluation input. Watertown, MA: Pathfinder International.

Boyer, E. L. (1990). Scholarship reconsidered: Priorities of the professoriate. Princeton, NJ: Princeton University Press.

Buller, M. K., \& Buller, D. B. (1987). Physicians' communication style and patient satisfaction. Journal of Health and Social Behavior, 28, 375-388.

Burnard, P., Gill, P., Stewart, K., Treasure, E., \& Chadwick, B. (2008). Analysing and presenting qualitative data. British Dental Journal, 204(8), 429-432.

Buttery, C. M., \& Moser, D. L. (1980). A combined family and community medicine clerkship. Journal of Family Practice, $11(2)$, 237-244.

Cevizci, S., Uluocak, S., Aslan, C., Gökulu, G., Bilir, O., \& Bakar, C. (2015). Prevalence of falls and associated risk factors among aged population: community based cross-sectional study from Turkey. Central European Journal of Public Health, 23(3), 233.

Chasteen, A. L., \& Pratt, J. (1999). The effect of age-related stereotypes on response initiation and execution. The Journal of General Psychology, 126(1), 17-36.

Chasteen, A. L., Schwarz, N., \& Park, D. C. (2002). The activation of aging stereotypes in younger and older adults. The Journals of Gerontology Series B: Psychological Sciences and Social Sciences, 57(6), 540-547.

Chen, D., Lew, R., Hershman, W., \& Orlander, J. (2007). A cross-sectional measurement of medical student empathy. Journal of General Internal Medicine, 22(10), 1434-1438. 
Clever, S. L., Jin, L., Levinson, W., \& Meltzer, D. O. (2008). Does doctor-patient communication affect patient satisfaction with hospital care? Results of an analysis with a novel instrumental variable. Health Services Research, 43(5p1), 1505-1519. https://doi.org/10.1111/j.1475-6773.2008.00849.x

Corson, D. (1998). Community-based education for indigenous cultures. Language Culture and Curriculum, 11(3), 238-249. https://doi.org/10.1080/07908319808666555

Çalışkan, D., Öncu, B., Köse, K., Ocaktan, M. E., \& Özdemir, O. (2007). Depression scores and associated factors in pregnant and non-pregnant women: a community-based study in Turkey. Journal of Psychosomatic Obstetrics \& Gynecology, 28(4), 195-200. https://doi.org/10.1080/01674820701450649

Finkelstein, A., Carmel, S., \& Bachner, Y. G. (2017). Physicians' communication styles as correlates of elderly cancer patients' satisfaction with their doctors. European Journal of Cancer Care, 26(1), e12399.

Gholamzadeh, S., Khastavaneh, M., Khademian, Z., \& Ghadakpour, S. (2018). The effects of empathy skills training on nursing students' empathy and attitudes toward elderly people. BMC Medical Education, 18(1), 1-7.

Hale, N. M. (1998). Effects of age and interpersonal contact on stereotyping of the elderly. Current Psychology, 17(1), 28-38.

Hojat, M., DeSantis, J., \& Gonnella, J. S. (2017). Patient perceptions of clinician's empathy: measurement and psychometrics. Journal of Patient Experience, 4(2), 78-83.

Hummert, M. L. (1990). Multiple stereotypes of elderly and young adults: A comparison of structure and evaluations. Psychology and Aging, 5(2), 182-193. https://doi.org/10.1037/0882-7974.5.2.182

Hunt, J. B., Bonham, C., \& Jones, L. (2011). Understanding the goals of service learning and community-based medical education: a systematic review. Academic Medicine, 86(2), 246-251.

Holmén, K., \& Furukawa, H. (2002). Loneliness, health and social network among elderly people-a follow-up study. Archives of Gerontology and Geriatrics, 35(3), 261-274.

İstatistiklerle yaşlılar, (2018). Republic of Turkey Ministry of Health. Retrieved from hastaliklar/Yasli_Sagligi/ raporlar_istatistikler/TUIK_Yasli_Istatistik_2018.pdf

Kelly, L., Walters, L., \& Rosenthal, D. (2014). Community-based medical education: Is success a result of meaningful personal learning experiences?. Education for Health, 27(1), 47-50.

Kharicha, K., Iliffe, S., Manthorpe, J., Chew-Graham, C. A., Cattan, M., Goodman, C., ... \& Walters, K. (2017). What do older people experiencing loneliness think about primary care or community based interventions to reduce loneliness? A qualitative study in E ngland. Health \& Social Care in the Community, 25(6), 1733-1742.

Kitzinger, J. (1995). Qualitative research: introducing focus groups. Bmj, 311(7000), 299-302.

Maguire, P., \& Pitceathly, C. (2002). Key communication skills and how to acquire them. Bmj, 325(7366), 697-700. Magzoub, M. E. M., \& Schmidt, H. G. (2000). A taxonomy of community-based medical education. Academic Medicine, 75(7), 699-707.

McLafferty, I. (2004). Focus group interviews as a data collecting strategy. Journal of Advanced Nursing, 48(2), 187-194.

Mooney, L. A., \& Edwards, B. (2001). Experiential learning in sociology: Service learning and other communitybased learning initiatives. Teaching Sociology, 29(2), 181-194. 
2017 National Population Projections Tables: Main Serries. US Census Bureau. Retrieved from https://www. census.gov/data/tables/2017/demo/popproj/2017-summarytables.html

Olson, C. J. (2003). A curriculum module enhances students' gerontological practice-related knowledge and attitudes. Journal of Gerontological Social Work, 38(4), 85-102.

Overview of the UK population: August 2019. Office for National Statistics. Retrieved from https://www.ons.gov. uk/peoplepopulationandcommunity/populationandmigration/populationestimates/articles/ overviewoftheukpopulation/august2019\#the-uks-population-is ageing

Pettigrew, T. F. (1998). Intergroup contact theory. Annual Review of Psychology, 49(1), 65-85.

Pohl, C. J., Malin, S., \& Kennell, L. (2014). Reinventing the home visit for undergraduate nursing students. Journal of Nursing Education, 53(12), 696-698.

Prihanti, G. (2017). The development of community based education (cbe) model's to support the achievement of empathy competence: First year of medical students. J Soc Sci Hum, 25(S), 97-106.

Schwartz, K, Joseph P. Simmons, L. (2001). Contact quality and attitudes toward the elderly. Educational Gerontology, 27(2), 127-137.

Söderhamn, O., Lindencrona, C., \& Gustavsson, S. M. (2001). Attitudes toward older people among nursing students and registered nurses in Sweden. Nurse Education Today, 21(3), 225-229.

Stacy, R., \& Spencer, J. (1999). Patients as teachers: a qualitative study of patients' views on their role in a community-based undergraduate project. Medical Education, 33(9), 688-694.

Stewart, M. A. (1995). Effective physician-patient communication and health outcomes: a review. CMAJ: Canadian Medical Association Journal, 152(9), 1423-1433.

Stueber, K. (2019). Empathy. In E. N. Zalta (Ed.). International Encyclopedia of Ethics. Retrieved from https://plato. stanford.edu/archives/fall2019/entries/empathy/

Sundler, A. J., Lindberg, E., Nilsson, C., \& Palmér, L. (2019). Qualitative thematic analysis based on descriptive phenomenology. Nursing Open, 6(3), 733-739.

Şimşek, H., Doğanay, S., Budak, R., \& Uçku, R. (2014). Relationship of socioeconomic status with health behaviors and self-perceived health in the elderly: A community-based study, Turkey. Geriatrics \& Gerontology International, 14(4), 960-968.

The Edinburg Declaration (August 12, 1988). World Federation for Medical Education. Retrieved from https:// wfme.org/download/the edinburgh-declaration/

Turan, J. M., \& Say, L. (2003). Community-based antenatal education in Istanbul, Turkey: Effects on health behaviours. Health Policy and Planning, 18(4), 391-398.

Yang, G., Kong, L., Zhao, W., Wan, X., Zhai, Y., Chen, L. C., \& Koplan, J. P. (2008). Emergence of chronic noncommunicable diseases in China. The Lancet, 372(9650), 1697-1705.

Wade, D. T. (2009). Holistic health care-what is it, and how can we achieve it?. In Nuffield Orthopaedic Centre's Annual General Meeting, Oxford, UK. Retrieved from https:// pdfs.semanticscholar.org/80af/ edfca2ffe3c96054aac6a85cf940a9c63a56.pdf 


\section{TABLES AND FIGURES}

Table 1: Participants of the Focus Group Study

\begin{tabular}{|c|c|}
\hline Group & Participants \\
\hline \multirow{5}{*}{$\begin{array}{l}\text { Focus Group } 1 \\
\text { Physiotherapy }\end{array}$} & P1 (female) \\
\hline & P2 (female) \\
\hline & P3 (female) \\
\hline & P4 (female) \\
\hline & P5 (male) \\
\hline \multirow{5}{*}{$\begin{array}{l}\text { Focus Group } 2 \\
\text { Elderly Care }\end{array}$} & P6 (female) \\
\hline & P7 (female) \\
\hline & P8 (female) \\
\hline & P9 (female) \\
\hline & P10 (female) \\
\hline \multirow{6}{*}{$\begin{array}{l}\text { Focus Group } 3 \\
\text { Nursing }\end{array}$} & P11 (female) \\
\hline & P12 (male) \\
\hline & P13 (female) \\
\hline & P14 (female) \\
\hline & P15 (female) \\
\hline & P16 (female) \\
\hline \multirow{6}{*}{$\begin{array}{l}\text { Focus Group } 4 \\
\text { Medical School }\end{array}$} & P17 (female) \\
\hline & P18 (female) \\
\hline & P19 (male) \\
\hline & P20 (female) \\
\hline & P21 (female) \\
\hline & P22 (male) \\
\hline
\end{tabular}


